\title{
Form (Form)
}

\author{
David E. Wellbery
}

To cite this article: Wellbery, David E. "Form (Form)." Goethe-Lexicon of Philosophical Concepts 1, no. 1 (2021): 45-52.

To link to this article: https://doi.org/10.5195/glpc.2021.38

Published by the University Library System, University of Pittsburgh.

\section{(c)}

Entries in this Lexicon are licensed under a Creative Commons Attribution 4.0 United States License.

Copyright @ the Author(s). 


\section{Form (Form)}

The concept of form today remains as indispensable to philosophical reflection as it was for Plato and Aristotle. In view of its centrality to Goethe's work, the concept may thus be considered one of the privileged themes for assessing Goethe's position in the Western philosophical tradition. The following remarks must pursue a more modest aim. Their purpose is to highlight sites of reflection in Goethe's oeuvre in which the concept of form does irreplaceable intellectual work. It is important to stress the selectivity of such a project, for to examine the peculiar inflection the concept of form undergoes in Goethe's work is to enter a field of intricately interwoven concepts. Kindred terms include Gestalt (form, shape, contour), (Um-) Gestaltung (transformation, formation), Typus (type), Urbild (archetype); crucial explicating concepts are Organisation (organization), Einheit (unity), and Idee (idea); syntactic and semantic linkages run inter alia to schaffen (to create) and Gewalt (in the sense of force, not violence); Morphologie is the science of form; negative concepts such as formlos (amorphous) and Chaos (chaos) likewise have their place. The entire nexus is central both to Goethe's aesthetics and to his scientific studies. Finally, nearly all the terms within the nexus are susceptible to poetic intensification, as exemplified in the verses from Pandora cited in the Introduction. A brief entry such as this can do no more than carve a slender path through this variegated semantic terrain.

\section{Introduction}

Sie steiget hernieder in tausend Gebilden, Sie schwebet auf Wassern, sie schreitet auf Gefilden, Nach heiligen Massen erglänzt sie und schallt, Und einzig veredelt die Form den Gehalt, Verleiht ihm, verleiht sich die höchste Gewalt, Mir erschien sie in Jugend-, in Frauen-Gestalt. $\left(\right.$ FA 1.6:685) ${ }^{1}$

She descends hereto in a thousand formations, She hovers on waters, bestrides these pastures, In sacred measures she shimmers and resounds, And it's solely the form that ennobles content, Grants it, grants itself the greatest of force, To me she appeared in youthful, in feminine contour.

To bring Goethe's form concept into view it is useful first to situate it within an array of ideal types, distinguishing it from an eidetic notion of form, on the one hand, and a constructivist notion of form, on the other hand.
The eidetic notion understands form as a conceptual essence in starkest opposition to matter and change. Plato (during one phase of his life) as well as Neo-Platonists (including Renaissance thinkers) may be considered representatives of this mode of thought. ${ }^{2}$ The crucial feature of the eidetic notion is that it attributes reality (being) to the formal essence and regards the instantiated, hence change-plagued form/material complex as ontologically deficient (an imitation). The constructivist notion, by contrast, understands form as the artifact of an operation of distinction. Emphasized here is the arbitrary act of delimitation that sets off a form from its background. Like the eidetic concept, the constructivist notion of form rests on a stark contrast, whereby the relevant contrasting pair now appears in such juxtapositions as form/environment or form/medium. Variants of this notional type can be found, for example, among the Gestalt theorists or in the systems theory of Niklas Luhmann. ${ }^{3}$ One may speculate that the sponsoring model of both notions is that of the outline ${ }^{4}$ a surmise that allows the specific character of the third slot in our heuristic typology to emerge into view. That slot is occupied by 
the notion of endogenous form, which understands form as a lawful process of formation actualized in an interplay of invariance and variation. Form thusly conceived is a genesis from within, a self-shaping governed by an inner principle. The relation of form and material is no longer one of opposition, but rather of interpenetration. While conceptually distinguishable, form and matter are not separable. My contention is that Goethe's notion of form belongs to the endogenous type. ${ }^{5}$ This is not to say that the thought of form remains unchanged throughout Goethe's career. On the contrary, one task of the following remarks is to chart some of its most important modifications. I do want to claim, however, that the notion of endogenous form brings the general framework into view within which Goethe's thought develops.

\section{An Early Discussion of Endogenous Form}

The first full-blown articulation of Goethe's concept of endogenous form appears in the appendix to Heinrich Leopold Wagner's translation of Louis-Sébastian Mercier's $D u$ Théâtre ou nouvel essai sur l'art dramatique (About the Theater or a new Essay on Dramatic Art) published in 1776. To be sure, this brief miscellany of two essays and a handful of poems-Aus Goethes Brieftasche (From Goethe's Briefcase) - initially castigates the reigning formalists among critics and aestheticians: "Es ist endlich einmal Zeit, daß man aufgehöret hat, über die Form dramatischer Stücke zu reden, über ihre Länge und Kürze, ihre Einheiten, ihren Anfang, ihr Mittel und Ende, und wie das Zeug alle hieß" (FA 1.18:174; It is finally time that one stops talking about the form of dramatic works, about their length and brevity, their unities, their beginning, middle, and end, and all that other stuff). Here it is important to note that a specific concept of form is being rejected, a concept based on a set of abstracted external features deemed normative and invariant. Often read as a rejection of rules, Goethe's objection is in fact based on the insight that such a concept of form cannot account for what a concept of form should account for, namely the "Ungebundenheit" (FA 1.18:174; un-tied-ness) that is, the genuine unity (as opposed to the mere "tying-together" of disparate components) of the dramatic work. What sort of notion would meet this desideratum? Goethe answers: "Deswegen gibts doch eine Form, die sich von jener unterscheidet, wie der innere Sinn vom äußern, die nicht mit Händen gegriffen, die gefühlt sein will" (FA 1.18:174; Therefore there is a form that distinguishes itself from that one, as the inner sense from the outer, one that cannot be grasped with hands, but must be felt). A few lines later he designates this type of form as "[die] inner[e] Form, die alle Formen in sich begreift, [...]" (FA 1.18:174; the inner form, which comprehends all forms in itself). So here we have a notion of form that (a) provides genuine unity, (b) is internal to the object (dramatic work) evincing the form, and (c) is apprehended not by an abstractive operation of the understanding, but rather by what Goethe designates as "feeling." Elevated to a definition: form is the inner principle of unity of an object, and that principle can be apprehended through the capacity of Gefühl.

\section{Metaphysical Considerations}

I shall return to the cognitive operation through which formal unity is apprehended further on, for it is a crucial issue that irradiates throughout Goethe's work. At this point, however, I want to call attention to a surprising turn in Goethe's argument, a turn that lifts the discussion of artistic unity into a metaphysical dimension. This occurs in the following sentence: "Jede Form, auch die gefühlteste, hat etwas Unwahres, allein sie ist ein für allemal das Glas, wodurch wir die heiligen Strahlen der verbreiteten Natur an das Herz der Menschen zum Feuerblick sammeln" (FA 1.18:174; Every form, even the most deeply felt, possesses a kind of untruth; but it alone is once and for all the glass through which we gather to a focal point at man's heart the sacred rays of dispersed nature into a fiery gaze). I gloss the thought compressed into this sentence as follows. There is but one principle of unity, and it is that exhibited in the oneness of the entirety of nature. Nature in toto, we might say, is the single instance of endogenous form. Given the finitude of human capacities, however, this extensive unity of nature cannot be grasped (made fully present to mind). What can be apprehended in feeling, however, are individualized forms in which the oneness of nature is concentrated, as if gathered to a single focal point. Qua finite item of our attention, such an object is characterized by a moment of untruth, but in its internal formedness it nonetheless intensively reflects the boundless unity of nature. To put this another way, the individual form is not merely one of an infinite number of component parts of nature; rather, due to its exhibition of an inner principle of unity, it participates 
in the oneness of nature. A full assessment of the significance of this thesis would require an examination of important antecedents to Goethe's thinking, specifically the Cambridge Platonist Ralph Cudworth with his notion of a "plastick" or formative Nature and Anthony Earl of Shaftesbury, who distinguishes three levels of form: the outward form of things, the "inward form" evinced in human mindedness, and a metaphysical instance that forms all things, including human minds. ${ }^{6}$ For our purposes, it would be even more revealing to trace the pattern of thought documented in the 1776 appendix as it resonates through later writings. Goethe's notes from his Spinoza studies in 1784-1785, for example, recapitulate the emphatic idea of wholeness or oneness of forms along with the idea that individual forms participate in the oneness of the entirety of nature. ${ }^{7}$ Karl Philipp Moritz's Über die bildende Nachahmung des Schönen (1788; On the Formative Imitation of the Beautiful), certainly one of the foundational documents of classical aesthetics, contains a clear echo of Goethe's "Feuerblick" (fiery gaze) metaphor: "Sie [the aesthetically formative "Bildungskraft"] muß alle jenen Verhältnisse des großen Ganzen, und in ihnen das höchste Schöne, wie an den Spitzen seiner Strahlen, in einen Brennpunkt fassen" (The aesthetically formative force must comprehend all those interrelations of the great whole, and in them the utmost beautiful, like the tips of rays grasped at one focal point). ${ }^{8}$ As a final example we may cite Goethe's essay on the Laokoon group published in the first issue of the Propyläen (1798): "Wenn man von einem trefflichen Kunstwerke sprechen will, so ist es fast nötig von der ganzen Kunst zu reden, denn es enthält sie ganz, [. . . ]" (FA 1.18:489; If one wishes to speak of a splendid artwork, then it is almost necessary to speak of art in its entirety, for the work wholly contains the latter).

\section{Mature Conceptions of Artistic Form}

With the final quotation we have arrived at Goethe's mature conception of art, a conception that rested on his intense study of the art and architecture of Italy and comes to expression in various essays written in the 1790s. Since these essays only incidentally make general theoretical claims, the best approach to Goethe's "classical" conception of artistic form is to construct a constellation of such claims, each of which touches on a feature of the organizing conception. I begin with a remark from the Einleitung (introduction) to the Propyläen which states that the artist must penetrate into the "depths" of things and of his own inner life in order "etwas geistischorganisches hervorzubringen, und seinem Kunstwerk einen solchen Gehalt, eine solche Form zu geben, wodurch es natürlich zugleich und übernatürlich erscheint" (FA 1.18:462; to bring forth something organically permeated by mindedness and to grant his work such content, such form, that it may appear simultaneously natural and supra-natural). A paralipomenon to the same essay offers this thought: "Die Naturschönheit ist den Gesetzen der Notwendigkeit unterworfen, die Kunstschönheit den Gesetzen des höchst gebildeten menschlichen Geistes; jene erscheinen uns gleichsam gebunden, diese gleichsam frei" (FA 1.18:477; Natural beauty is subject to the laws of necessity, aesthetic beauty to the laws of the most cultivated human mind; the former appears to us, as it were, bound, the latter, as it were, free). A brief essay in dialogue form, also from the Propyläen, maintains: "Ein vollkommenes Kunstwerk ist ein Werk des menschlichen Geistes, und in diesem Sinne auch ein Werk der Natur" (FA 1.18:506; A perfect artwork is a work of the human spirit and, in this sense, also a work of nature). ${ }^{9}$ The same piece brings out the important point that artistic truth is "eine innere Wahrheit, die aus der Konsequenz eines Kunstwerks entspringt [. . .]" (FA 1.18:504; an inner truth that emerges out of the consistency of the artwork). The finding that most forcefully steps out from this constellation of statements bears on the prominence of the term Geist, which has replaced the term Gefühl from the appendix to Wagner's Mercier translation as the designation for the aspect of mindedness out of which form emerges and through which it is apprehended. Scholarship has yet to trace the accession of the concept of Geist to such a central position in Goethe's thought. The term begins to assert itself in the diary of Goethe's Italian journey, specifically in connection with his experience of Palladio's work, ${ }^{10}$ but its full semantic range still requires exploration. Nonetheless, our constellation of quotations does enable us to identify four characteristic features of the activity specific to Geist: (a) it actualizes itself in the articulation of organically organized products; (b) it operates according to norms that it legislates itself (autonomy or, better, heautonomy); (c) as regards these features it is similar to Nature (natürlich), but-precisely due to the autonomous character of its activity - distinct from nature (übernatürlich); (d) its products (successful artworks) exhibit a truth that resides in their systematic 
unity (a synonym of "geistig-organisch"). Viewed synthetically, the four determinations give us an image of formative activity as a freely self-legislating production that brings forth works exhibiting genuine unity by virtue of their internal organization, which is also the source of their unique mode of truth.

\section{The Form/Content Distinction}

Having brought this Geist-centered conception of the formative process into view, we can turn to the terminological use of the word Form, which appears in the first of the passages cited in the foregoing paragraph together with the term Gehalt. The temptation to be avoided here is to imagine that there are two separable entities, a content that can, as it were, be extruded from its form and a form that is imposed on some content from without. Rather, we should think of the Form/Gehalt pair as marking the dual aspects of the products of formative activity. My suspicion is that the emergence of this vocabulary in Goethe's writing was influenced by his reading of Fichte's Ueber den Begriff der Wissenschaftslehre (On the Concept of the Science of Knowledge), which he received from the philosopher in $1794 .{ }^{11}$ Be that as it may, the term Form refers to articulate structure, while the term Gehalt designates the semantic purport of that structure. Formative activity brings an experiential sector, a zone of felt importance, a dimension of significance to articulation. Looking back at the first sentence cited in the previous paragraph, we can now interpret it to mean that the product of artistic Geist is achieved by giving articulate organization (Form) to an otherwise inchoate experiential field. Indeed, it is only in the achievement of articulate structure that experience becomes a Gehalt at all. Something like this is the message of the passage from Pandora cited at the outset. The activity attributed to Form and the rhyming of Gewalt (in the sense of creative force), Gehalt, and Gestalt say as much. ${ }^{12}$ Finally, the concluding verses of Dauer im Wechsel (1803; Constancy in Change) return us to our initial observation regarding Geist as the instance of formative activity:

Danke, daß die Gunst der Musen

Unvergängliches verheißt,

Den Gehalt in deinem Busen

Und die Form in deinem Geist. (FA 1.2:79)
Thank the favor of the muses

that promised the imperishable, the content in your bosom and the form in your mind.

\section{Natural Form}

I want to conclude by at least limning the contours of Goethe's concept of natural form and its place in his scientific studies. ${ }^{13}$ A pair of lines from the poem Metamorphose der Tiere (1820; Metamorphosis of Animals) takes us to the central issue:

Alle Glieder bilden sich aus nach ew'gen Gesetzen Und die seltenste Form bewahrt im Geheimen das Urbild. (FA 1.2:499.14-15)
All limbs developmentally unfold according to eternal laws
And the rarest of forms preserves in secret the ur-image [archetype].

The formative process (bilden) brings forth the various parts or members of the animal creatures according to an inner principle (Gesetz) and, although this process results in sometimes unusual external forms, even such apparently aberrant variants preserve the normative archetype (Urbild). Two form concepts are operative here: one (Form) designating the visually manifested configuration, the other (Urbild) the abstract organizing principle of the creature in its unity. In his review of Goethe's Versuch die Metamorphose der Pflanzen zu Erklären (1790; Attempt to Explain the Metamorphosis of Plants), August Batsch perfectly captured this conceptual configuration in this sentence: "Dabei zeigt er [Goethe] überall, wie die Übergänge des einen in den anderen Teil der Gewächse vermöge der Identität derselben Urform der Organisation geschehen" (Goethe thereby demonstrates again and again how the transitions from one part of growths to another occur by virtue of the identity of the same ur-form of organization). ${ }^{14} \mathrm{~A}$ fuller explication of this fundamental thought is contained in Goethe's 1796 lectures on osteology:

Sollte es denn aber unmöglich sein, da wir einmal anerkennen daß die schaffende Gewalt nach einem 
allgemeinen Schema die vollkommeneren organischen Naturen erzeugt und entwickelt, dieses Urbild, wo nicht den Sinnen, doch dem Geiste darzustellen, nach ihm, als nach einer Norm unsere Beschreibungen auszuarbeiten und, indem solche von der Gestalt der verschiedenen Tiere abgezogen wäre, die verschiedensten Gestalten wieder auf sie zurückzuführen? (FA 1.24:270)

Should it then, however, be impossible, given that we recognize how the creative force generates and develops the more perfect organic natures according to a general schema [Schema], to represent this normative archetype [Urbild], if not to the senses, then to the mind, and to work out our descriptions according to it as according to a norm, insofar as such descriptions are drawn from the form [Gestalt $]$ of various animals, and lead the most varied of forms back to it?

Three aspects of this passage bear emphasis. First, the point of the rhetorical question is to specify the status and purpose of what this particular lecture calls a Typus, an additional term for the formative principle here explicated via the synonyms Urbild and Schema. At issue in the cited passage, however, is not merely the logical necessity of holding an archetypal notion of form, but, more centrally, the indispensability of such a notion in the concrete description of variant species. This is the second aspect to which I wish to call attention. The form, in the sense of Urbild or Typus, is a norm of relevant description. In our efforts to understand a particular feature of a creature, our guide must be a pre-understanding of the organized unity of the living being. Just such a conception of part/ whole relations is what form (in the sense of Urbild) is. ${ }^{15}$ The final aspect of the cited passage I want to underline is that the mode of apprehension of Form (in the sense of Urbild or Urform or Typus) is attributed to Geist. This resonates with the foregoing comments on the place of Geist in Goethe's mature account of aesthetic experience and for this reason deserves a brief, closing remark.

\section{Form and Intuition}

Perhaps no concept of Goethe's is as prominently featured in the secondary literature as that of Anschauung, to which an entry of this lexicon will be devoted. Here I simply want to emphasize that, in the apprehension of both aesthetic and natural form, intuition is permeated by Geist, which is to say that it is not merely a receptive or strictly perceptual activity, but rather has an active, projective component. Indeed, in a remark on the botanist C.A. Wolff, Goethe notes that his forerunner's descriptions were hampered by his failure to understand that there is a difference between "Sehen und Sehen." What is required for the adequate understanding of plant forms is "daß die Geistes-Augen mit den Augen des Leibes in stetem lebendigem Bunde [. . . w wirken" (FA 1.24:433; that the eyes of the mind effectively act in constant vital association with the eyes of the body). Just because he only saw what he passively saw as he moved from observation to observation - that is, because he didn't see with Geistes-Augen the organization of the whole that provides the norm of description-Wolff was fated to commit errors of description. This is a compelling critique of empiricism, but Goethe has deeper claims to make regarding intuitive apprehension. We can begin to bring out these claims by citing a marginal remark to Fichte's 1794 Begriff der Wissenschaftslehre. Where Fichte refers to the objectivity of knowledge as a relation to a "von uns unabhängige[n] Natur" (nature independent from us), Goethe's penciled note reads: "aber doch mit uns verbundne, deren lebendige Theile wir sind" (but, however, [a nature] connected to us, of which we are the living parts). ${ }^{16}$ Fichte's strict severance of nature from our acts of knowing is countered by what can only be called a metaphysical claim that grounds the human capacity for genuine knowledge of nature in our own naturalness. If we now turn to Goethe's brief essay discussing his response to Kant's Kritik der Urteilskraft (1790; Critique of the Power of Judgment), which was published under the title Anschauende Urteilskraft (Intuitive Power of Judgment) in the first of the Hefte zur Morphologie (1817; Morphological Notebooks), we can see how this notion of our relatedness to nature flows into the account of an intuitive understanding. For it is here that Goethe asserts "daß wir uns, durch das Anschauen einer immer schaffenden Natur, zur geistigen Teilnahme an ihren Produktionen würdig machen" (FA 1.24:448; that, through the perceptual intuition of an evercreative nature, we make ourselves worthy of a mental participation in her productions). Our participation in the productions of nature is not material, but geistig, and this can only mean the intellectual production of 
the form that inheres in the natural object attended to. Just insofar as it grasps the formative principle, our intuitive-intellectual activity participates in and, in this sense, becomes identical with the natural form. To think the form is to be mindfully in a relationship of identity with the form. Exactly this is what one of Goethe's most famous aphorisms states: "Es gibt eine zarte Empirie, die sich mit dem Gegenstand innigst identisch macht, und dadurch zur eigentlichen Theorie wird" (FA 1.15:149; There is a supple empiricism that makes itself most intimately identitical with its object and thereby becomes genuine theory), a process Goethe describes as a "Steigerung unseres geistigen Vermögens" (FA 1.25:113; intensification of our mental capacity). As we have seen, the same intensification of formative activity occurs in the experience of art. And for this reason, the definition of the beautiful Goethe offers in the Campagne in Frankreich (1822; Campaign in France) is entirely consonant with his theory of natural form: "das Schöne sei, wenn wir das gesetzmäßig Lebendige in seiner größten Tätigkeit und Vollkommenheit schauen, wodurch wir zur Reproduktion gereizt uns gleichfalls lebendig und in höchste Tätigkeit gesetzt fühlen [. . .]" (FA 1.16:546; the beautiful is when we intuit that which is lawfully alive in its immense activity and perfection, through which we are stimulated to reproduce it and simultaneously feel ourselves alive and stirred to highest activity).
David E. Wellbery

University of Chicago 


\section{Notes}

${ }^{1}$ Johann Wolfgang von Goethe, Pandora, 1.673-78. Recent scholarship that has emphasized the form-theoretical dimension of the 1808 pageant: David E. Wellbery, Goethes 'Pandora'. Dramatisierung einer Urgeschichte der Moderne (Munich: Bayrische Akademie der Wissenschaften, 2017); Sabine Schneider and Juliane Vogel, eds., Epiphanie der Form. Goethes 'Pandora' im Licht seiner Form- und Kulturkonzepte, (Göttingen: Wallstein, 2018).

${ }^{2}$ See the 1924 essays by Ernst Cassirer and Erwin Panofsky in John Michael Krois, ed., Ernst Cassirer: 'Eidos und Eidolon. Das Problem des Schönen und der Kunst in Platons Dialogen' [and] Erwin Panofsky: 'Idea. Ein Beitrag zur Begriffsgeschichte der älteren Kunsttheorie' (Hamburg: Philo Fine Arts, 2008).

${ }^{3}$ See e.g., Niklas Luhmann, Die Kunst der Gesellschaft (Frankfurt a.M.: Suhrkamp, 1996), the chapter "Medium und Form," 165-214; F. Molnar und V. Molnar, "Noise, Form, Art," Leonardo 22, no. 1 (1989), 15-20. This interpretation as regards Plato's eidos concept is advanced in Martin Heidegger, Der Ursprung des Kunstwerkes (Stuttgart: Reclam, 1960), 19.

${ }^{4}$ This interpretation as regards Plato's eidos concept is advanced in Martin Heidegger, Der Ursprung des Kunstwerkes (Stuttgart: Reclam, 1960), 19.

${ }^{5}$ David Wellbery, "Form und Idee. Skizze eines Begriffsfeldes um 1800," in Morphologie und Moderne. Goethes 'Anschauliches Denken' in den Geistes- und Kulturwissenschaften seit 1800, ed. Jonas Maatsch (Berlin: De Gruyter, 2014), 17-42. For another formulation of the endogenous form concept see this passage from Hegel's Vorlesungen über die Ästhetik: "Denn das Zusammenstimmen von Begriff und Erscheinung ist vollendete Durchdringung. Deshalb bleibt die äußere Form und Gestalt nicht von dem äußeren Stoff getrennt oder demselben mechanisch zu sonstigen anderen Zwecken aufgedrückt, sondern sie erscheint als die der Realität ihrem Begriff nach innewohnende und sich herausgestaltende Form." G.W.F. Hegel, Werke in zwanzig Bänden, ed. Eva Moldenhauer and Karl Markus Michel, 20 vols. (Frankfurt a.M: Suhrkamp, 1970), 13:156. Let this note flag the fact that the thought of endogenous form reaches into the writings of virtually all Goethe's major contemporaries.

${ }^{6}$ Ralph Cudworth, "The Digression concerning the Plastick Life of Nature, or an Artificial, Orderly and Methodical Nature," in The Cambridge Neoplatonists, ed. C.A. Patrides (Cambridge: Cambridge UP, 1969), 288-325; Anthony, Earl of Shaftesbury, Characteristics of Men, Manners, Opinions, Times, ed. John M. Robertson (Indianapolis \& New York: Hackett Publishers, 1964), 2:133. Distinctions between Shaftesbury's and Goethe's conceptions, often neglected in the scholarship, are emphasized in Wellbery, "Form und Idee," 21.

7 "Alle beschränkte Existenzen sind im Unendlichen, sind aber keine Teile des Unendlichen sie nehmen vielmehr Teil an der Unendlichkeit" (FA 1.18:188).

${ }^{8}$ Karl Philipp Moritz, Die Signatur des Schönen und andere Schriften zur Begründung der Autonomieästhetik (Hamburg: Philo Arts, 2009), 45. On Goethe's shaping influence on Moritz's treatise see Wellbery, "Form und Idee," 29-31.
${ }^{9}$ From the essay Über Wahrheit und Wahrscheinlichkeit der Kunstwerke (Concerning Truth and Verisimilitude in Works of Art).

${ }^{10} \mathrm{~A}$ reasonable conjecture is that the concept of Geist from which Goethe's usage of the term in the texts of the 1790s (and later) stems is the notion of an active formative principle that inheres in and, indeed, is the very source of art in its highest expression, in short: the Geist of art fully achieved. Such is the Geist that the individual artist must accede to in order to achieve full mastery. The diary of the Italian journey characterizes the experience of Palladio's art in this way: "Die Revolution, die ich voraussah und die jetzt in mir vorgeht, ist die in jedem Künstler entstand, der lange emsig der Natur treu gewesen und nun die Überbleibsel des alten grosen Geists erblickte, die Seele quoll auf und er fühlte eine innere Art von Verklärung sein selbst ein Gefühl von freyerem Leben, höherer Existenz Leichtigkeit und Grazie" (FA 1.15:686; The revolution that I foresaw and is now happening inside me happens in every artist who, diligently true to nature for a long time, caught sight of the vestige of the ancient [and] capacious Mind [Spirit], [and] his soul welled up and he sensed a kind of inner transfiguration of his own being, a sensation of a freer life, of a higher existence lightness and grace).

${ }^{11}$ Wolf von Engelhart, ed., Goethes Fichtestudien. Faksimile-Edition von Goethes Handexemplar der Programmschrift 'Ueber den Begriff der Wissenschaftslehre,' Schriften der Goethe-Gesellschaft 71 (Berlin: Springer, 2004). Goethe marks, for example, this sentence: "Die Form des absoluten ersten Grundsatzes der Wissenschaftslehre ist also durch ihn selbst nicht nur gegeben sondern auch schlechthin gültig für den Gehalt desselben aufgestellt" (23 of the facsimile). Particularly interesting from the point of view of aesthetics is this version of the same thought: "In der Wissenschaftslehre ist die Form vom Gehalte, oder der Gehalt von der Form nie getrennt; in jedem ihrer Sätze ist beides auf das innigste vereinigt" (45 of the facsimile).

${ }^{12}$ See also Goethe's remark in a letter to Zelter (January 15, 1813): “[. . .] wollte ich nur sagen, daß die Kunst, wie sie sich im höchsten Künstler darstellt, eine so gewaltsam lebendige Form erschafft, daß sie jeden Stoff veredelt und verwandelt" (FA 2.7:149; I merely meant to say that art, as represented by the best artists, creates a so powerfully vibrant form that it ennobles and transforms any material).

${ }^{13}$ Recent research has brought this topic to the center of Goethe studies. See Eckart Förster, Die 25 Jahre der Philosophie (Frankfurt a.M.: Klostermann, 2011), 233-76; Eva Geulen, Aus dem Leben der Form. Goethes Morphologie und die Nager (Berlin: August Verlag, 2016); Daniel Carranza, The Gift of Metamorphosis: Goethe's Poetic Science of Form (Dissertation: University of Chicago, 2020).

${ }^{14}$ The review appeared in the Jenaer allgemeine Literaturzeitung 3, no. 1 (1802): 521. Cited after Olaf Breidbach, Goethes Metamorphosenlehre (München: Fink, 2006), 84.

${ }^{15}$ It reaches beyond the limits of this entry, but is nonetheless worth mentioning that this point has hermeneutic consequences for the understanding of art and literature.

${ }^{16}$ See note 11, Goethes Fichtestudien, 43. 


\section{Related Entries in the GLPC}

Anschauung (intuition), Gestalt (shape, form), (Um-) Gestaltung (transformation), Typus (primordial or ur-image), Urbild (primordial or ur-image), Organisation (organization), Einheit (unity), Idee (idea), Schaffen (create, make, acquire), Gewalt (force), Morphologie (morphology), Formlos (formless), Chaos (chaos)

\section{Works Cited and Further Reading}

Apel, Friedmar. "Der lebendige Blick. Goethes Kunstanschauung." In Goethe und die Kunst, edited by Sabine Schulze, 571-78. Ostfildern: Verlag Georg Hatje, 1994.

Breidbach, Olaf. Goethes Metamorphosenlehre. Munich: Fink, 2006.

Carranza, Daniel. “The Gift of Metamorphosis: Goethe's Poetic Science of Form." PhD diss., University of Chicago, 2020.

Cassirer, Ernst. Gesammelte Werke. Edited by Birgit Recki. Vol. 7: Freiheit und Form. Studien zur deutschen Geistesgeschichte, edited Reinold Schmücker. Hamburg: Felix Meiner Verlag, 2001.

Cudworth, Ralph. "The Digression concerning the Plastick Life of Nature, or an Artificial, Orderly and Methodical Nature." In The Cambridge Neoplatonists, edited by C.A. Patrides, 288-325. Cambridge: Cambridge UP, 1969.

Förster, Eckart. Die 25 Jahre der Philosophie. Frankfurt a.M.: Klostermann, 2011.

Geulen, Eva. Aus dem Leben der Form. Goethes Morphologie und die Nager. Berlin: August Verlag, 2016.

Goethe, Johann Wolfgang. Goethes Fichtestudien. Faksimile-Edition von Goethes Handexemplar der Programmschrift 'Ueber den Begriff der Wissenschaftslehre'. Edited and with commentary by Wolf von Engelhardt. Schriften der Goethe-Gesellschaft, vol. 71. Berlin: Springer, 2004.

Hegel, G.W.F. Werke. Edited by Eva Moldenhauer and Karl Markus Michel. Frankfurt a.M: Suhrkamp, 1970.

Heidegger, Martin. Der Ursprung des Kunstwerkes. Stuttgart: Reclam, 1960.

Jolles, Mattijs. Goethes Kunstanschauung. Bern: Francke, 1957.
Kommerell, Max. "Faust II. Zum Verständnis der Form." In Geist und Buchstabe der Dichtung, 9-74. Frankfurt a.M.: Vittorio Klostermann, 1991.

Krois, John Michael, ed. Ernst Cassirer. "Eidos und Eidolon. Das Problem des Schönen und der Kunst in Platons Dialogen" (1924) and Erwin Panofsky, "Idea. Ein Beitrag zur Begriffsgeschichte der älteren Kunsttheorie" (1924). Hamburg: Philo Fine Arts, 2008.

Luhmann, Niklas. Die Kunst der Gesellschaft. Frankfurt a.M.: Suhrkamp, 1996.

F. Molnar and V. Molnar, "Noise, Form, Art." Leonardo 22, no.1 (1989): 15-20.

Moritz, Karl Philipp. Die Signatur des Schönen und andere Schriften zur Begründung der Autonomieästhetik. Hamburg: Philo Arts, 2009.

Osterkamp, Ernst. “'Aus dem Gesichtspunkt reiner Menschlichkeit'. Goethes Preisausgaben für bildende Künstler 1799-1805." In Goethe und die Kunst, edited by Sabine Schulze, 310-42. Ostfildern: Verlag Georg Hatje, 1994.

Richards, Robert J. The Romantic Conception of Life. Science and Philosophy in the Age of Goethe. Chicago: University of Chicago Press, 2002.

Shaftesbury, Anthony, Earl of. Characteristics of Men, Manners, Opinions, Times. Edited by John M. Robertson. Indianapolis \& New York: Hackett Publishers, 1964.

Schmitz, Hermann. Goethes Altersdenken im problemgeschichtlichen Zusammenhang. Bonn: Bouvier, 1959.

Schneider, Sabine and Juliane Vogel, eds. Epiphanie der Form. Goethes 'Pandora' im Licht seiner Form- und Kulturkonzepte. Göttingen: Wallstein, 2018.

Wellbery, David E. "Form und Idee. Skizze eines Begriffsfeldes um 1800." In Morphologie und Moderne. Goethes 'Anschauliches Denken' in den Geistes- und Kulturwissenschaften seit 1800, edited by Jonas Maatsch, 17-42. Berlin: De Gruyter, 2014.

-. Goethes 'Pandora'. Dramatisierung einer Urgeschichte der Moderne. Munich: Bayrische Akademie der Wissenschaften, 2017.

-. "Selbstbezüglichkeit und Ursprünglichkeit der Form." In Formbildung und Formbegriff. Das Formdenken der Moderne, edited by Markus Klammer, Malika Maskarinec, Rahel Villinger, \& Ralph Ubl, 181-200. Munich: Wilhelm Fink, 2019. 